\title{
HUBUNGAN RIWAYAT SAKIT DAN ASUPAN GIZI (ENERGI DAN PROTEIN) DENGAN STATUS GIZI LANSIA DI WILAYAH KERJA PUSKESMAS PADANGMATINGGI KOTA PADANGSIDIMPUAN
}

\author{
Johanna Christy \\ Dosen STIKes Imelda Medan, Jl. Bilal No 52, Medan \\ email:johanna.hasibuan@yahoo.co.id
}

\begin{abstract}
One of the increasing benchmarks of the progress of a nation is seen from the life expectancy of its population. Increasing life expectancy is reflected in the increasing number of elderly (elderly) population. The increasingly elderly population in Indonesia will have a major impact on the management of health problems. This study aims to see aims to know the history of illness, energy intake and protein intake with nutritional status in the elderly in the work area of Padangmatinggi in Padangsidimpuan Health Center. This research type is quantitative with cross sectional research design. This study was conducted by assessing the food method of food recall 24 hours. Nutritional status with IMT / U. The sample in this study amounted to 100 people who are elderly. Data analysis is univariate, and bivariate with Chi Square Test. The result of bivariate test shows that there is correlation between history of illness $(p=0,000)$, energy intake $(p=0.000)$, and protein intake $(p=0.000)$ with nutritional status. Cadres should more often give counseling about balanced nutrition to the community, especially elderly to improve knowledge, attitudes, and behavior of balanced nutrition in elderly and always monitor nutritional status of elderly through posyandu elderly in order to maintain normal BMI. The health office is more often to monitor the nutritional status and health of the elderly in the working area of Padang municipal health center of Padangsidimpuan in order to maintain the normal nutritional status in the elderly and the elderly to avoid degenerative diseases.
\end{abstract}

Keywords: History of illness, Nutritional Intake, Nutritional Status, Elderly.

\section{PENDAHULUAN}

Salah satu peningkatan tolak ukur kemajuan suatu bangsa terlihat dari usia harapan hidup penduduknya. Peningkatan usia harapan hidup tercermin dari makin meningkatnya jumlah penduduk lanjut usia (lansia). Keadaan ini tidak hanya terjadi di Negara industry tetapi juga di Negara berkembang. Di banyak Negara-negara di dunia, penduduk tua meningkat dengan pesat. Proporsi penduduk lanjut usi yaitu 60 tahun ke atas mencapai sekitar 10 persen dari penduduk dunia. Dan di proyeksikan menjadi sekitar 22 persen pada tahun 2050. Laju peningkatan tertinggi di Afrika Utara dan China serta beberapa Negara Asia dan terendah di Sub-Saharan Afrika. Total populasi penduduk berusia lanjut di atas 60 tahun pada tahun 2025 diperkirakan lebih dari 800 juta jiwa, sekitar dau pertiganya tinggal di Negara berkembang dan mayoritas adalah perempuan (Ambartama, 2014).

Indonesia mengalami peningkatan populasi penduduk lansia yang amat pesat dari $4,48 \%$ pada tahun 1971 (5,3 juta jiwa) menjadi $9,77 \%$ pada tahun 2010 (23,9 juta jiwa). Bahkan pada tahun 2020 diprediksi akan terjadi ledakan jumlah penduduk lansia sebesar $11,34 \%$ atau sekitar 28,8 juta jiwa. 
Dari proporsinya tampak bahwa Indonesia telah memasuki era penduduk berstruktur tua (aging population), yaitu suatu Negara dengan proporsi penduduk usia lanjut telah berada pada patokan penduduk berstruktur tua, yaitu $7,5 \%$ dari jumlah total penduduk dan dalam waktu 20 tahun lagi jumlah lansia Indonesia akan melebihi jumlah usia balita.

Penduduk usia lanjut di Indonesia yang semakin bertambah akan membawa pengaruh besar dalam pengelolaan masalah kesehatannya. Saat ini angka kesakitan akibat penyakit degenerative meningkat jumlahnya disamping masih adanya kasus penyakit infeksi dan masalah gizi. Pada masa lansia, kemunduran fungsi dan kualitas organ tubuh dapat mengurangi kekebalan tubuh dan meningkatkan oksidan (racun) yang akhirnya menimbulkan berbagai penyakit atau gangguan metabolic terutama hipertensi, jantung, diabetes mellitus dan kanker. Ada lima penyakit utama yang banyak di derita penduduk lansia di Indonesia diantaranya anemia (50\%), penyakit jantung pembuluh darah (29,5\%), infeksi saluran pernafasan $(12,2 \%)$, kanker $(12,2 \%)$ dan TBC $(11,5 \%)$ (Depkes RI, 2013).

Masalah gizi usia lanjut merupakan rangkaian proses masalah gizi sejak usia muda yang manifestasinya timbul setelah tua. Masalah gizi yang sering diderita usia lanjut adalah gizi kurang dan gizi lebih. Darmojo (2013) melaporkan bahwa lansia di Indonesia yang dalam keadaan kurang gizi sebanyak $3,4 \%$, berat badan kuang sebesar $28,3 \%$, berat badan ideal berjumlah $42,4 \%$, berat badan lebih sebanyak $6,7 \%$ dan obesitas sebanyak $3,4 \%$. Sedangkan konsusi energy dan protein rata-rata lansia < 80\% AKG. Kondisi kurang gizi tanpa disadari terjadi karena gejala yang muncul hamper tak terlihat, sampai usia lanjut tersebut jatuh dalam kondisi gizi buruk. Kurang gizi dapat terjadi secara mendadak dialami atau berlagsung dalam waktu cukup lama. Penyebab kurang gizi pada usia lanjut antara lain pengetahuan tentang gizi yang kurang, makan tidak enak karena berkurangnya fungsi alat perasa dan penciuman, banyak gizi yang tanggal/ompong sehingga untuk makan terasa sakit, nafsu makan berkurang karena kurang aktivitas, kesepian, depresi, penyakit kronis, efek samping dari obat, alcohol dan rokok.

Data Dinas Kesehatan Provinsi Sumatera Utara (2016) menunjukkan proporsi lansia gizi kurang sebesar $15,3 \%$. Tingginya angka status gizi buruk pada lansia beresiko terhadap komplikasi penyakit yang akan mempengaruhi kualitas hidup. Faktor-faktor yang menyebabkan kurangnya gizi pada lansia adalah keterbatasan ekonomi keluarga, penyakit-penyakit kronis, kurangnya pengetahuan tentang gizi, hilangnya gigi, kesalahan dalam pola makan dan menurunnya energi.

Semakin meningkatnya jumlah penduduk lansia dengan berbagai masalah gizi dan kesehatan menyebabkan bertambah besarnya kebutuhan akan perawatan di institusi dan pengawasan yang lebih intensif (Fitri, 2013) Selain peran keluarga dan masyarakat dalam upaya merawat lansia diperlukan juga peran pemerintah dalam meberikan fasilitas pada lansia yaitu menyediakan tempat perawatan bagi lansia melalui program-program pemerintah yang ada, misalnya posyandu lansia, yang dapat memberikan pelayanan kesehatan seperti pengecekan kesehatan, penyuluhan menu sehat, olahraga lansia di dalam masyarakat dampai ke tingkat keluarahan.

Berdasarkan survei awal yang dilakukan di Puskesmas Padangmatinggi Kota Padang sidimpuan didapatkan informasi bahwa wilayah kerja Puskesmas Padangmatinggi Kota Padangsidimpuan terdiri dari 8 kelurahan, yaitu kelurahan Aek Tampang, kelurahan Padang Matinggi, kelurahan Silandit, kelurahan Wek V, kelurahan Sitamiang, kelurahan Kampung Losung, Kelurahan Padang Matinggi Lestari dan kelurahan Sitamiang Baru. Selain itu diperoleh data bahwa jumlah lansia yang berumur 60 tahun keatas sebanyak 1333, laki- 
laki sebanyak 632 orang dan perempuan 701 orang.

Rumusan masalah penelitian ini adalah belum diketahuinya hubungan riwayat sakit dan asupan gizi (energy dan protein) dengan status gizi lansia di wilayah kerja puskesmas Padangmatinggi kota Padangsidimpuan.

Tujuan penelitian ini adalah untuk mengetahui hubungan riwayat sakit dan asupan gizi (energy dan protein) dengan status gizi lansia di wilayah kerja puskesmas Padangmatinggi kota Padangsidimpuan. Manfaat penelitin ini adalah dapat menggambarkan status gizi lansia di wilayah kerja puskesmas Padangmatinggi kota Padangsidimpuan sehingga dapat dijadikan pedoman dalam meningkatkan pengetahuan, sikap dan perilaku gizi seimbang pada lansia.

\section{METODE}

Jenis penelitian ini adalah pendekatan kuantitatif dengan desain cross-sectional.
Variabel dependen pada penelitian ini adalah status gizi lansia yang diukur berdasarkan IMT sedangkan variabel independen adalah: riwayat sakit, asupan energi dan asupan protein. Penelitian ini dilakukan di wilayah kerja Puskesmas Padangmatinggi Kota Padangsidimpuan yang terdiri dari 8 kelurahan. Pemilihan lokasi dilakukan dengan pertimbangan banyaknya lansia yang berumur $\geq 60$ tahun di wilayah kerja Puskesmas Padangmatinggi yaitu sebanyak 1333 orang laki-laki sebanyak 632 orang dan perempuan 701 orang.

Teknik pengambilan sampling atau teknik sampling dalam penelitian ini menggunakan teknik probability sampling dengan proportional random sampling, untuk mendapatkan sampel yang representatif maka diambil sampel dari masing-masing kelurahan/desa dengan teknik proportional random sampling.

Tabel 1. Besar Sampel Setiap Kelurahan

\begin{tabular}{llclc}
\hline No & Kelurahan & Jumlah Sampel & Rekapitulasi Perhitungan Populasi & Jumlah Sampel \\
\hline 1 & Aek Tampang & 252 & $252 / 1333 \times 100=18,90$ & 19 \\
\hline 2 & Padang Matinggi & 183 & $183 / 1333 \times 100=13,72$ & 14 \\
\hline 3 & Silandit & 107 & $107 / 1333 \times 100=8$ & 8 \\
\hline 4 & Wek V & 207 & $207 / 1333 \times 100=15,52$ & 16 \\
\hline 5 & Sitamiang & 174 & $174 / 1333 \times 100=13$ & 13 \\
\hline 6 & Kampung Losung & 170 & $170 / 1333 \times 100=12,75$ & 6 \\
\hline 7 & Padang Matinggi Lestari & 90 & $90 / 1333 \times 100=6$ & 11 \\
\hline 8 & Sitamiang Baru & 150 & $150 / 1333 \times 100=11$ & $\mathbf{1 0 0}$ \\
\hline \multicolumn{7}{c}{ Total } & $\mathbf{1 3 3 3}$ & & \\
\hline
\end{tabular}

Pengumpulan data dilakukan dengan melakukan wawancara pengisian kuesioner yang berisi pertanyaan untuk mendapatkan data identitas sampel (nama, umur dan alamat), jenis kelamin, pendidikan, pekerjaan, riwayat sakit. Status gizi diambil dari kuesioner dan pengukuran antropometri (BB dan TB) serta pengukuran panjang depa pada responden yang tidak dapat berdiri tegak di masing-masing kelurahan yang sudah terpilih. Pengambilan data konsumsi makanan untuk melihat kebiasaan makan dan gambaran tingkat kecukupan makanan (total energi dan protein), dengan menggunakan metode yaitu Formulir Food Recall $1 \times 24$ jam pada hari biasa untuk mengetahui jumlah asupan energi dan protein dalam ukuran rumah tangga lalu dikonversi dalam ukuran berat (gram). Formulir Recall Aktivitas Fisik untuk mengukur besarnya energi yang dikeluarkan (kkal) per kilogram berat badan dalam 24 jam. Analisis data yang dilakukan pada penelitian ini terbagi 2 analisa yaitu analisis univariat, bivariat dengan menggunakan chi square. 


\section{HASIL}

\section{Uji Univariat}

Adapun karakteristik lansia menurut umur dan jenis kelamin dapat dilihat pada tabel dibawah ini.

Tabel 2. Distribusi Responden Berdasarkan Karakteristik pada Lansia di Wilayah Kerja Puskesmas Padangmatinggi Kota Padangsidimpuan

\begin{tabular}{lcc}
\hline Karakteristik & Jumlah & Persentase \\
\hline Umur & & \\
\hline Lansia(60-74 tahun) & 59 & 59 \\
\hline Lansia tua (>74 tahun) & 41 & 41 \\
\hline Total & $\mathbf{1 0 0}$ & $\mathbf{1 0 0}$ \\
\hline Jenis Kelamin & & \\
\hline Laki-laki & 37 & 37 \\
\hline Perempuan & 63 & 63 \\
\hline \multicolumn{1}{c}{ Total } & $\mathbf{1 0 0}$ & $\mathbf{1 0 0}$ \\
\hline
\end{tabular}

Gambaran riwayat penyakit pada lansia di wilayah kerja Puskesmas Padangmatinggi tidak hanya lansia yang mempunyai penyakit degeneratif tetapi juga penyakit lainnya. Tabel 2 menunjukkan bahwa sebagian besar lansia mempunyai riwayat penyakit yaitu sebanyak 69 orang $(69,0 \%)$ dan yang tidak mempunyai riwayat penyakit sebanyak 31 orang $(31,0 \%)$.

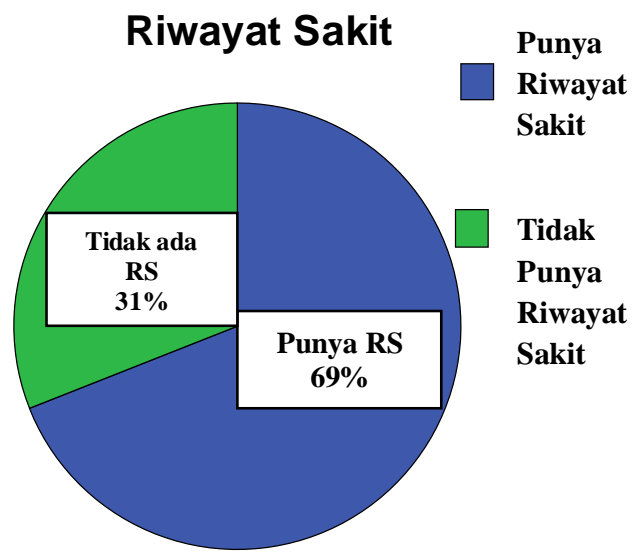

Gambar 1. Distribusi Riwayat Sakit pada Lansia di Wilayah Kerja Puskesmas Padangmatinggi Kota Padangsidimpuan

Hasil penelitian jumlah konsumsi energi gambar 1 Lansia pada penelitian ini menunjukkan sebagian besar pemenuhan asupan energi kurang yaitu sebesar 41,0\% .

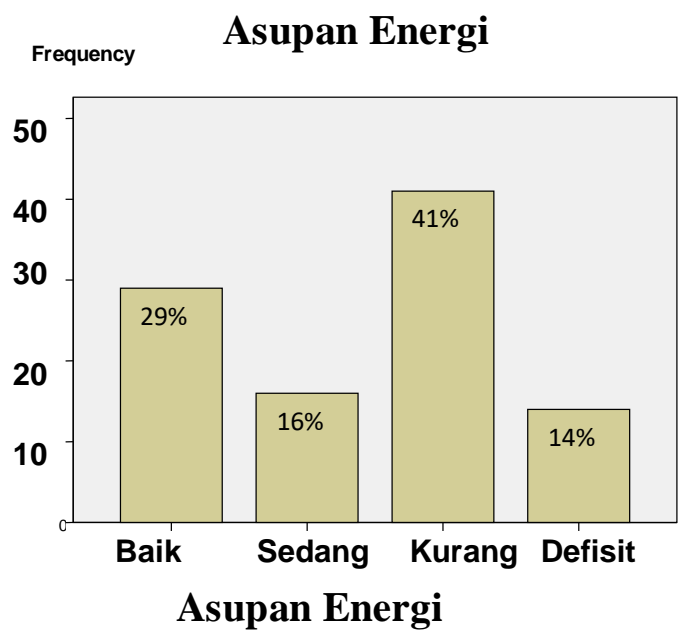

Gambar 2. Distribusi Asupan Energi pada

Lansia di Wilayah Kerja Puskesmas

Padangmatinggi Kota Padangsidimpuan

Hasil penelitian jumlah konsumsi energi gambar 2 Lansia pada penelitian ini menunjukkan sebagian besar pemenuhan asupan energi kurang yaitu sebesar 40,0\% .

Frequency

Asupan Protein

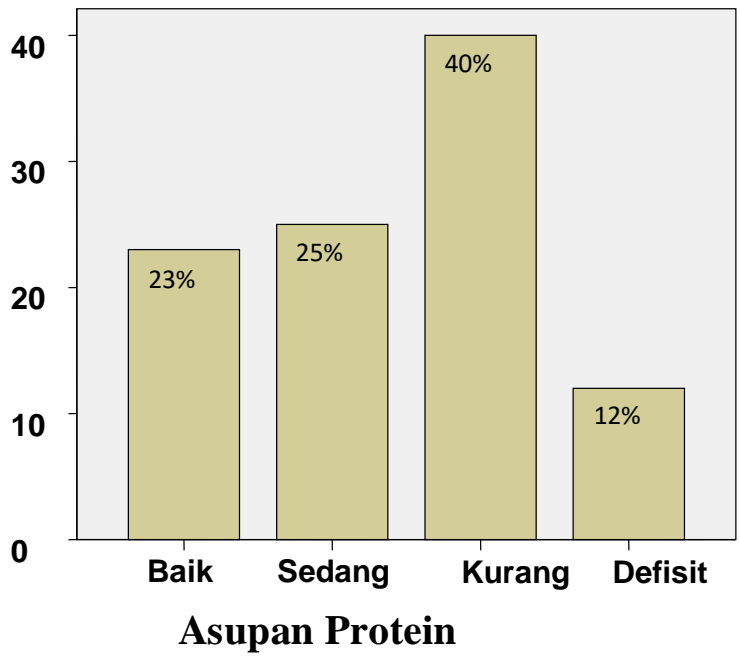

Gambar 3. Distribusi Asupan Protein pada Lansia di Wilayah Kerja Puskesmas Padangmatinggi Kota Padangsidimpuan 


\section{Uji Bivariat}

Hasil uji statistik ini menunjukkan bahwa proporsi lansia dengan status gizi kurus, lebih tinggi pada lansia dengan riwayat sakit sebesar 54 (78,3\%) dibandingkan dengan lansia yang tidak memiliki riwayat sakit yaitu sebesar 10 (32,3\%). Sedangkan lansia dengan status gizi normal proporsinya lebih banyak pada lansia yang tidak memiliki riwayat sakit sebesar $12(38,7 \%)$ dibandingkan lansia dengan yang memiliki riwayat sakit sebesar 1 $(1,4 \%)$. Berdasarkan hasil uji diperoleh hasil signifikasi $\mathrm{p}=0,000(<0,05)$ maka terdapat hubungan antara riwayat sakit dengan status gizi.

Tabel 3. Hasil Analisis Bivariat antara Riwayat Sakit Lansia dengan Status Gizi

\begin{tabular}{|c|c|c|c|c|c|c|c|c|c|}
\hline \multirow[t]{3}{*}{ Karakteristik } & \multicolumn{6}{|c|}{ Status Gizi } & \multirow{2}{*}{\multicolumn{2}{|c|}{ Total }} & \multirow[t]{3}{*}{$p$} \\
\hline & \multicolumn{2}{|c|}{ Kurang } & \multicolumn{2}{|c|}{ Normal } & \multicolumn{2}{|c|}{ Lebih } & & & \\
\hline & $\mathbf{n}$ & $\%$ & $\mathbf{N}$ & $\%$ & $\mathbf{n}$ & $\%$ & $\mathbf{n}$ & $\%$ & \\
\hline Riwayat Sakit & & & & & & & & & 0,000 \\
\hline Sakit & 54 & 78,3 & 1 & 1,4 & 14 & 20,3 & 69 & 100 & \\
\hline Tidak Sakit & 10 & 32,3 & 12 & 38,7 & 9 & 29 & 31 & 100 & \\
\hline
\end{tabular}

Hal ini sejalan dengan penelitian yang diilakukan oleh (Fitri, 2013) korelasi antara status penyakit 3 bulan terakhir dengan status gizi lansia adalah signifikan $(\mathrm{p}=0,000)<0,05$ yang berarti ada hubungan antara status penyakit 3 bulan terakhir dengan status gizi lansia. Hubungan itu positif, yang artinya semakin baik status penyakit seseorang maka semakin baik pula status gizinya atau sebaliknya. Penyakit menyebabkan menurunnya daya tahan tubuh lansia, sehingga dalam proses mempertahankan daya tahan tubuh menjadi baik, maka lansia membutuhkan gizi yang cukup dalam proses pemulihan seperti protein, karbohidrat dan vitamin (Simanjuntak, 2010).

Pada penelitian Fitri (2013) terdapat hubungan yang kuat antara status gizi dengan riwayat sakit. Seseorang yang sakit dapat mengalami kekurangan nafsu makan sehingga dapat mempengaruhi berat badan orang tersebut. Pada penelitian Handayani (2014) tidak terdapat hubungan bermakna antara status gizi dengan riwayat sakit.

Hasil analisis hubungan statistik antara asupan energi dengan status gizi diperoleh nilai $\mathrm{p}$ sebesar $0,000 \quad(\mathrm{p}<0,05)$ yang menunjukkan bahwa variabel asupan energi berhubungan signifikan dengan status gizi lansia, yang berarti ada hubungan antara asupan energi dengan status gizi lansia. Hal ini sejalan dengan penelitian Wulandari (2015) terdapat hubungan yang signifikan antara status gizi dengan asupan energi. Berdasarkan uji multivariate tidak terdapat pengaruh yang signifikan antara status gizi dengan asupan protein.

Tabel 4. Hasil Analisis Bivariat antara Asupan Gizi dengan Status Gizi

\begin{tabular}{|c|c|c|c|c|c|c|c|c|c|}
\hline \multirow[t]{3}{*}{ Asupan Gizi } & \multicolumn{6}{|c|}{ Status Gizi } & \multirow{2}{*}{\multicolumn{2}{|c|}{ Total }} & \multirow{3}{*}{$p$} \\
\hline & \multicolumn{2}{|c|}{ Kurang } & \multicolumn{2}{|c|}{ Normal } & \multicolumn{2}{|c|}{ Lebih } & & & \\
\hline & $\mathbf{n}$ & $\%$ & $\mathbf{N}$ & $\%$ & $\mathbf{n}$ & $\%$ & $\mathbf{n}$ & $\%$ & \\
\hline Asupan Energi & & & & & & & & & 0,000 \\
\hline Baik & 0 & 0 & 12 & 41,4 & 17 & 58,6 & 29 & 100 & \\
\hline Sedang & 9 & 56,3 & 1 & 6,3 & 6 & 37,5 & 16 & 100 & \\
\hline Kurang & 41 & 100 & 0 & 0 & 0 & 0 & 41 & 100 & \\
\hline Defisit & 14 & 100 & 0 & 0 & 0 & 0 & 14 & 100 & \\
\hline Asupan Protein & & & & & & & & & 0,000 \\
\hline Baik & 0 & 0 & 10 & 43,5 & 13 & 56,5 & 23 & 100 & \\
\hline
\end{tabular}




\begin{tabular}{lcccccccc}
\hline Sedang & 12 & 48 & 3 & 12 & 10 & 40 & 25 & 100 \\
\hline Kurang & 40 & 100 & 0 & 0 & 0 & 0 & 40 & 100 \\
\hline Defisit & 12 & 100 & 0 & 0 & 0 & 0 & 12 & 100 \\
\hline
\end{tabular}

Data asupan energi diperoleh dari wawancara dengan menggunakan metode food recall 1 x 24 jam. Metode ini merupakan pengulangan ingatan 24 jam yang lalu dan bertujuan untuk memperkirakan asupan pangan individu. Prinsipnya adalah mencatat jenis dan jumlah bahan makanan yang dikonsumsi pada periode 24 jam yang lalu. Selain biaya yang relatif murah, metode ini dapat dilakukan pada responden yang buta huruf. Namun metode ini juga memiliki kekurangan yaitu kurang representatif untuk menggambarkan kebiasaan makanan inividu, bila hanya dilakukan satu hari.

Berdasarkan hasil penelitian tentang asupan energi ditemukan bahwa sebesar $40 \%$ lansia berada pada kategori kurang. Artinya bahwa tingkat kecukupan energi per hari 70$80 \%$ AKG. Hasil uji bivariat menunjukkan terdapat hubungan signifikan antara status gizi dengan konsumsi protein lansia. Penelitian ini sejalan dengan Wirakusumah (2015) menyatakan ada hubungan signifikan antara status gizi dengan asupan protein. Mengacu pada hasil uji tersebut dapat dijelaskan bahwa semakin baik asupan protein seseorang maka semakin baik status gizinya atau sebaliknya. Namun hal ini bertentangan dengan penelitian Simanjuntak (2010) yang menyatakan tidak ada hubungan bermaknan antara status gizi dengan asupan protein.

Menurut teori yang ada, bila seseorang mengalami penuaan maka terjadi perubahan pada beberapa komposisi kimia dalam tubuh manusia serta beberapa struktur makroskopis dalam tubuh, sehingga orang yang mengalami penuaan selalu dalam resiko malnutrisi karena penurunan asupan makanan sebagai akibat perubahan fungsi usus, metabolisme tidak efektif, dan defek utilisasi nutrien. Sehingga,asupan gizi yang kurang adekuat bisa menjadi alasan mengapa indeks masa tubuh menjadi turun saat orang yang mengalami penuaan (Ambartama, 2014). Dalam penelitian ini kebanyakan lansia memiliki tingkat kecukupan protein yang kurang (40\%) dan deficit (12\%).

\section{KESIMPULAN}

1. Terdapat hubungan yang signifikan antara riwayat sakit dengan status gizi lansia di wilayah kerja puskesmas Padangmatinggi kota Padang sidimpuan.

2. Terdapat hubungan yang signifikan antara asupan gizi (energy dan protein) dengan status gizi lansia di wilayah kerja puskesmas Padangmatinggi kota Padang sidimpuan.

\section{SARAN}

1. Kader hendaknya lebih sering memberikan penyuluhan tentang gizi seimbang kepada masyarakat terutama lansia untuk meningkatkan pengetahuan, sikap, dan perilaku gizi seimbang pada lansia dan selalu memonitoring status gizi lansia melalui posyandu lansia guna mempertahankan IMT normal.

2. Dinkes lebih sering memonitoring status gizi dan kesehatan lansia di wilayah kerja puskesmas Padangmatinggi kota Padang sidimpuan guna mempertahankan status gizi normal pada lansia dan lansia terhindar dari penyakit degenratif.

\section{DAFTAR PUSTAKA}

Ambartana. (2014). Hubungan Status Gizi terhadap Kekuatan Otot Lanjut Usia di Kabupaten Gianyar. Denpasar: FK Universitas Udayana.

Darmojo, B., Hadi, M. (2013). Buku Ajar Geriatri: Ilmu Kesehatan Usia Lanjut. Jakarta: FK UI. 
Departemen Kesehatan RI. (2003). Pedoman Tatalaksana Gizi Usia Lanjut Untuk Tenaga Kesehatan. Jakarta: Direktorat Jenderal Bina Kesehatan Masyarakat.

Depkes RI. (2013). Pusat Data dan Informasi Kemenetrian Kesehatan RI. Jakarta: Depkes RI.

Fitri, Subekti. (2013). Skripsi: Analisis Karakteristik Usia Lanjut Berhubungan Dengan Status Gizi Di Posyandu Lansia Dusun Wonogiri Jatirejo Lendah Kulon Progo. Yogyakarta: Fakultas Keperawatan. Sekolah Tinggi Ilmu Kesehatan Aisyitah Yogyakarta. Diakses pada 30 Maret 2017.

Handayani, T. (2014). Skripsi: Faktor-Faktor yang Berhubungan Status Gizi Karyawan Departemen Operasional PT. Jakarta Internasional Container Termina (JICT) Tanjung Priok 2002. Depok: FKM UI.

Nisa, H. (2004). Tesis: Faktor Determinan Status Gizi Lansia Penghuni Panti Werdha Pemerintah DKI Jakarta.
Jakarta: Prodi Peminatan Gizi Kesehatan Masyarakat, Fakultas Kesehatan Masyarakat UI.

Rusilanti, dkk. (2012). Aspek Psikososial, AKtivitas Fisik, dan Konsumsi Makanan Lansia di Masyarakat. Jurnal Gizi dan Pangan. November 2006 1(2):1-7.

Simanjuntak, E. (2010). Tesis: Status Gizi Lanjut Usia Di Daerah Pedesaan, Kecamatan Porsea, Kabupaten Toba Samosir, Provinsi Sumatera Utara Tahun 2010. Depok: FKM UI.

Wirakusumah. (2015). Cara Aman dan Efektif Menurunkan Berat Badan. Jakarta: Gramedia Pustaka Umum.

Wulandari, P.D.A. (2015). Skripsi: Hubungan Antara Asupan Energi, Asupan Protein Dan Aktivitas Fisik Terhadap Status Gizipenduduk Lanjut Usia Di Wilayah Kerja Upt Kesmas Blahbatuh Ii,Kecamatan Blahbatuh, Kabupaten Gianyar. Bali: FK Udayana. 